Neurolmages
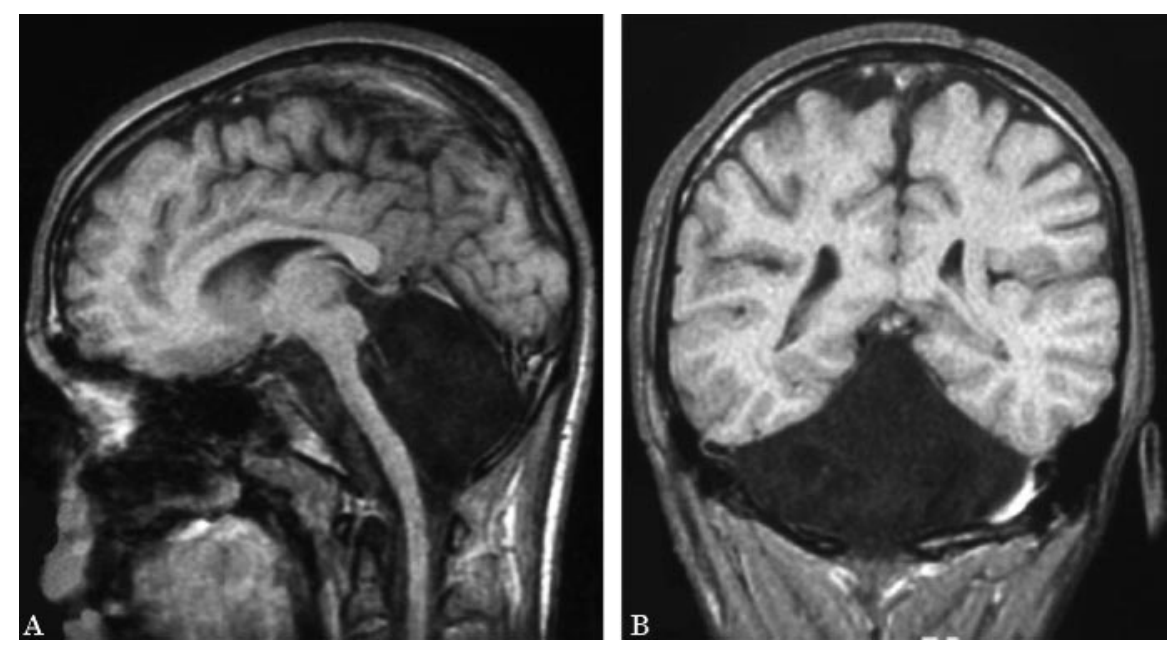

Figure. T1-weighted sagittal (A) and coronal (B) brain MRIs showing total cerebellar agenesis.

\section{Cerebellar agenesis}

LIGHT Luigi Titomanlio, MD; Alfonso Romano, $M D$; and VIDEO Ennio Del Giudice, MD, Naples, Italy

A 17-year-old boy with a history of neonatal hypotonia was first observed by us at age 4 years because of persistent ataxia. Brain MRI revealed isolate cerebellar agenesis (CA) (figure), the empty cerebellar space having its signal similar to CSF in all performed sequences. At age 17 years he showed moderate ataxia

Address correspondence and reprints requests to Dr. Ennio Del Giudice, Child Neurology Unit, Department of Pediatrics, Via S. Pansini, 5, 80131 Naples, Italy. (video 1), mild dysmetria (video 2), and no nystagmus. Neuropsychological evaluation evidenced mild mental retardation. Further examination was normal. He attends a normal school, to which he gets by bicycle.

Total or subtotal CA is an extremely rare congenital defect and is thought to be associated with profound deficits in movement. ${ }^{1}$ Clinical presentation ranges from early death to variable degrees of cerebellar dysfunction. ${ }^{2}$

Reports of living patients address the question of whether CA is compatible with functional motor development. Cerebellar development occurs early during embryogenesis, so that plasticity of the remaining brain could explain functional compensation.

1. Glickstein M. Cerebellar agenesis. Brain 1994;117:1209-1212.

2. Timmann D, Dimitrova A, Hein-Kropp C, Wilhelm H, Dorfler A. Cerebellar agenesis: clinical, neuropsychological and MR findings. Neurocase 2003;5:402-413. 


\title{
Neurology
}

\author{
Cerebellar agenesis \\ Luigi Titomanlio, Alfonso Romano and Ennio Del Giudice \\ Neurology 2005;64;E21 \\ DOI 10.1212/WNL.64.6.E21
}

\section{This information is current as of March 21, 2005}

\section{Updated Information \&}

Services

Supplementary Material

References

Citations

Permissions \& Licensing

Reprints including high resolution figures, can be found at: http://n.neurology.org/content/64/6/E21.full

Supplementary material can be found at: http://n.neurology.org/content/suppl/2005/03/20/64.6.E21.DC1 http://n.neurology.org/content/supp1/2007/04/02/64.6.E21.DC2

This article cites 2 articles, 0 of which you can access for free at: http://n.neurology.org/content/64/6/E21.full\#ref-list-1

This article has been cited by 1 HighWire-hosted articles: http://n.neurology.org/content/64/6/E21.full\#\#otherarticles

Information about reproducing this article in parts (figures,tables) or in its entirety can be found online at:

http://www.neurology.org/about/about_the_journal\#permissions

Information about ordering reprints can be found online: http://n.neurology.org/subscribers/advertise

Neurology ${ }^{\circledR}$ is the official journal of the American Academy of Neurology. Published continuously since 1951, it is now a weekly with 48 issues per year. Copyright . All rights reserved. Print ISSN: 0028-3878. Online ISSN: 1526-632X.

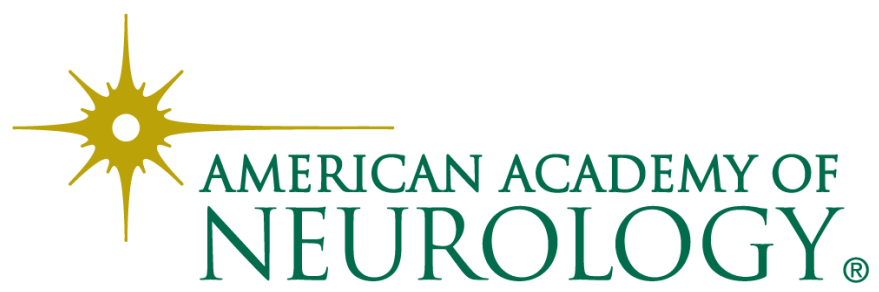

